DOI: $10.1515 /$ pts-2017-0014

\title{
TRIBOLOGICAL PROPERTIES OF PVD Ti/C-N NANOCOATNIGS
}

\author{
A.Leitans, J.Lungevics, J.Rudzitis, A.Filipovs \\ Institute of Mechanical Engineering, \\ Riga Technical University, \\ 6 Ezermalas Str., LV-1006, Riga, LATVIA \\ e-mail:mti@rtu.lv
}

\begin{abstract}
The present paper discusses and analyses tribological properties of various coatings that increase surface wear resistance. Four Ti/C-N nanocoatings with different coating deposition settings are analysed. Tribological and metrological tests on the samples are performed: $2 \mathrm{D}$ and $3 \mathrm{D}$ parameters of the surface roughness are measured with modern profilometer, and friction coefficient is measured with CSM Instruments equipment. Roughness parameters $\mathrm{Ra}, \mathrm{Sa}$, $\mathrm{Sz}, \mathrm{Str}, \mathrm{Sds}, \mathrm{Vmp}, \mathrm{Vmc}$ and friction coefficient at $6 \mathrm{~N}$ load are determined during the experiment. The examined samples have many pores, which is the main reason for relatively large values of roughness parameter. A slight wear is identified in all four samples as well; its friction coefficient values range from 0,21 to 0.29 . Wear rate values are not calculated for the investigated coatings, as no expressed tribotracks are detected on the coating surface.
\end{abstract} sistance.

Keywords: magnetron deposition, nanocoatings, roughness, wear re-

\section{INTRODUCTION}

The wear of elements in the mechanical engineering sector is a topical problem, which is associated with the reduction of actuating mechanism life span and the decrease of efficient performance. As it is known, when two components contact with each other, the friction forces between the surfaces emerge both during component slip and rotation movements. Therefore, the presence of friction significantly reduces the energy efficiency of the mechanism, efficiency as such, as well as endproduct quality.

In order to reduce friction and ensure high wear resistance, coatings obtained from magnetron deposition technology are applied; their main advantages are the conservation and biochemical functionality of substrate material properties. Such coatings evenly adhere to the substrate and are free from micro cracks. The coatings of Ti/C-N type have a high level of surface adhesion when applied to the component, ensuring the provision of a minimum friction coefficient obtained in contact with another component. These types of coating also have both high micro hardness and 
high permissible operating temperatures [1], [4].

\section{PREPARING SUBSTRATES FOR DEPOSITION EXPERIMENT}

The substrate material is chrome steel $100 \mathrm{Cr} 6$ according to DIN 17230:1980; round samples with a diameter of $18 \mathrm{~mm}$ served as substrates. Prior to the deposition procedure, all samples were subject to ultrasonic cleaning using "Lotonaxe" degreasing bath, then cleaning in water-alcohol solution was performed and drying with hot air was carried out. After that, when the experimental samples were fixed and put in the chamber, the substrate surface was activated in argon atmosphere using ion beam equipment.

Deposition equipment VU-VSM 600/4 was used in order to perform Ti/C-N coating deposition. Deposition process was implemented following a satellite method, i.e., magnetron horizontally opposite location was used during the deposition time.

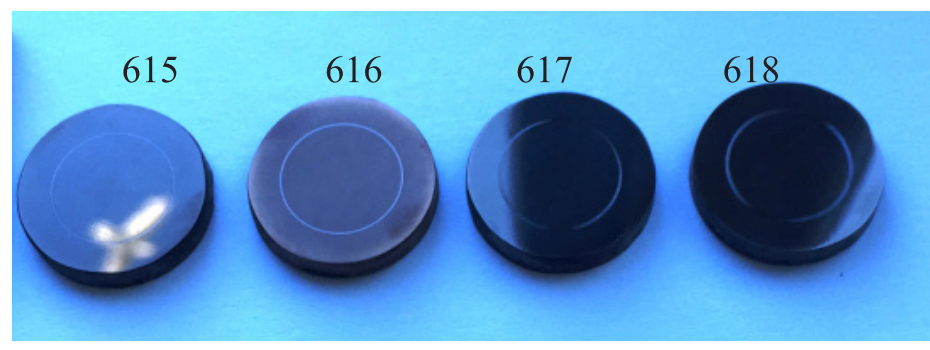

Fig. 1. Samples with Ti/C-N coating.

During deposition, sample No. 615 had the highest rotational speed; subsequently, smaller nanolayers were deposited. Sample No. 616 had higher TiN concentration, but sample No. 618 was the closest to the targets.

Table 1

Cu/C Coating Deposition Regimes

\begin{tabular}{|l|c|c|c|c|c|}
\hline No. & $\begin{array}{c}\text { Nanostructured } \\
\text { coating }\end{array}$ & Density, $\mu \mathrm{m}$ & $\begin{array}{c}\text { Sample rotation } \\
\text { degree }\end{array}$ & $\begin{array}{c}\text { Distance from } \\
\text { magnetron to } \\
\text { component, } \mathrm{mm}\end{array}$ & $\begin{array}{c}\text { Carousel rotation } \\
\text { speed, rpm }\end{array}$ \\
\hline 1 & 615 & 3.9 & 2 & 100 & 3 \\
\hline 2 & 616 & 4.2 & 2 & 100 & 2 \\
\hline 3 & 617 & 3.9 & 2 & 100 & 2 \\
\hline 4 & 618 & 3 & 2 & 60 & 2 \\
\hline
\end{tabular}

\section{EXPERIMENTAL PART}

To assess exploitation qualities of Ti/C-N surface coatings, it is important to analyse the surface topography and $2 \mathrm{D}$ and $3 \mathrm{D}$ roughness parameters, as well as the friction coefficient values and wear intensity. 
Modern measuring equipment Taylor Hobson Intra 50 was used for roughness measuring experiments. It belongs to a profilometer group of contact type measurement methods, which means that the machine is scanning the studied surface directly sliding over it with a thin hard metal needle Standard Stylus Arm 112/2009, which has a peak rounding radius of $2 \mu \mathrm{m}$ and pressure force on the studied surface of $1 \mathrm{mn}$, thus obtaining information on actual surface roughness character, i.e., profile chart.

During the experiment, measurement process settings were defined:

- individual profile chart length (X-axis) - $2 \mathrm{~mm}$;

- measured point number on each individual profile chart - 400 points;

- $\quad$ parallel profile chart number - 400 pieces;

- needle movement speed on X-axis $-0.5 \mathrm{~mm} / \mathrm{s}$.

In the performed experiments, a $2 \times 2 \mathrm{~mm}$ large sample surface fragment was explored. There were 400 mutually parallel profile chart measurements taken within the investigated fragment. 400 points that characterise the surface profile were displayed in each profile chart obtained. Overall, for a $2 \times 2 \mathrm{~mm}$ large working area, a measurement matrix with 160,000 points was obtained, from which the equipment software formed a 3D surface image, which was then subjected to filtering operations in order to get a real surface topography.

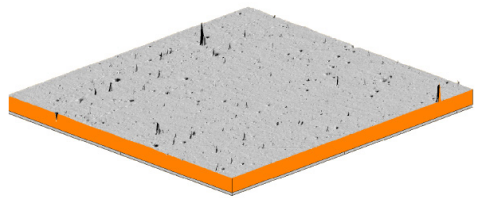

615

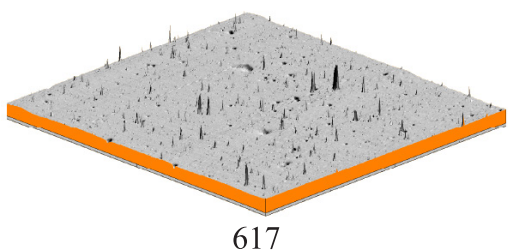

617

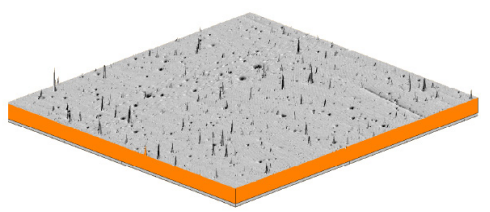

616

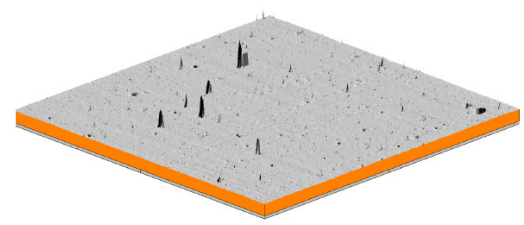

618

Fig. 2. 3D photo simulations of $\mathrm{Ti} / \mathrm{C}-\mathrm{N}$ naocoating.

Table 2 summarises 2D surface roughness ( $\mathrm{Ra}$ ) and 3D ( $\mathrm{Sa}, \mathrm{Sz}, \mathrm{Sds}, \mathrm{Str})$ parameters [3].

Overview of 2D and 3D Measurement Results

\begin{tabular}{|l|c|c|c|c|c|c|c|}
\hline \multirow{2}{*}{ Sample } & $\mathrm{Ra}$ & $\mathrm{Sa}$ & $\mathrm{Sz}$ & $\mathrm{Sds}$ & \multirow{2}{*}{$\mathrm{Str}$} & $\mathrm{Vmp}$ & $\mathrm{Vmc}$ \\
\cline { 2 - 5 } \cline { 7 - 8 } & $(\mu \mathrm{m})$ & $(\mu \mathrm{m})$ & $(\mu \mathrm{m})$ & $\left(\mathrm{pks} / \mathrm{mm}^{2}\right)$ & & $\left(\mathrm{mm}^{3} / \mathrm{mm}^{2}\right)$ & $\left(\mathrm{mm}^{3} / \mathrm{mm}^{2}\right)$ \\
\hline 615 & 0.0263 & 0.0239 & 4.29 & 1644 & 0.693 & $2.41 \mathrm{E}-04$ & $1.97 \mathrm{E}-03$ \\
\hline 616 & 0.0385 & 0.0262 & 4.3 & 1813 & 0.62 & $2.35 \mathrm{E}-04$ & $1.75 \mathrm{E}-03$ \\
\hline 617 & 0.0349 & 0.0391 & 5.16 & 2055 & 0.5 & $2.25 \mathrm{E}-04$ & $1.60 \mathrm{E}-03$ \\
\hline 618 & 0.0224 & 0.028 & 4.55 & 1585 & 0.67 & $8.91 \mathrm{E}-05$ & $6.59 \mathrm{E}-04$ \\
\hline
\end{tabular}


The recieved data allow concluding that the samples have a substantial amount of pores, which also serve as the main reason for relatively large values of roughness parameter (see Table 2). Although the coatings as such are completely isotropic, their isotropy Str characterising parameter value does not exceed 0.69, which is explained by the fact that the coatings copy substrate surfaces with pronounced surface treatment direction, i.e., surfaces are anisotropic.

To obtain information on tribological properties of the samples studied in the article, friction coefficient measurements of all four investigated samples No. 615, $616,617,618$ were taken [2]. The present slip friction experiments were carried out using CSM Instruments tribometer, following the ball-on-disc scheme (see Fig. 3), where the disk was represented with the sample substrate with the coating, which was rotating, while the ball was a stationary tribometer element. This method complies with ASTM G99 tribology test standard. Experiment settings can be observed in Table 3.

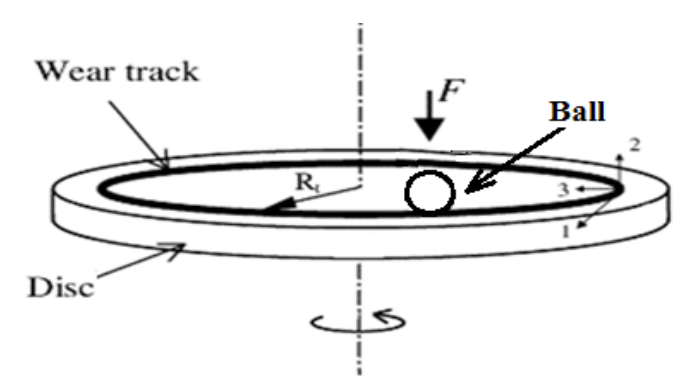

Fig. 3. "Ball-on-disc" test equipment scheme.

Table 3

Experiment Settings

\begin{tabular}{|c|c|}
\hline Tracking force & $6 \mathrm{~N}$ \\
\hline Sample rotation number & $1500 \mathrm{cycles}$ \\
\hline Linear speed of friction pair & $0.05 \mathrm{~m} / \mathrm{s}$ \\
\hline Tribological track radius & $6 \mathrm{~mm}$ \\
\hline Ball diameter & $6 \mathrm{~mm}$ \\
\hline Ball material & $100 \mathrm{Cr} 6$ (EN) \\
\hline Surface cleaning & Alchohol solution \\
\hline Atmosphere & Air \\
\hline Temperature & $22{ }^{\circ} \mathrm{C}$ (indoors) \\
\hline Humidity & $40 \%$ (indoors) \\
\hline
\end{tabular}

To gain information on wear resistance of the studied sample, wear resistance experiments were carried out, which resulted in getting wear tracks - tribological tracks. To evaluate the wear resistance of the samples, it is necessary to know crosssectional areas of tribological track. The parameter which is of interest may be obtained using contact type Surtronic 25 profilometer and, if necessary (in case the cross-sectional area of tribological track is very small), via Intra 50.

The measurements were carried out following the provided algorithm: 
1. the studied sample was placed on the profilometer table;

2. three independent cross-sectional area measurements with the following profilometer settings were performed:

- measurement track length $1_{t}-1 \mathrm{~mm}$;

- resolution range (for Surtronic 25 profilometer) $-10 \mu \mathrm{m}$.

Figure 4 shows measurement positioning on the sample:

Researched sample

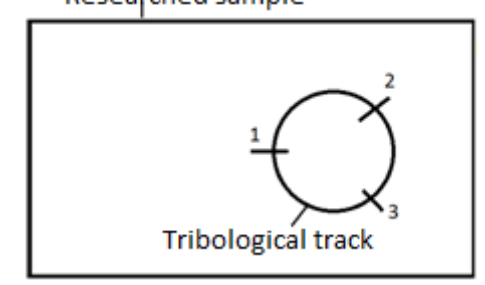

Fig. 4. Positioning of cross-sectional measurement of tribological track on the sample.

1. the profile chart post-treatment was performed, following the provided algorithm:

- making profile chart levelling by means of Leveling tool;

- bringing closer the profile chart part, which was of interest, using Zoom function;

- calculating the cross-sectional area of tribological track via Surface of a Hole/Peak function.

2. the average value of tribological track cross-sectional area was calculated. This value was used for further calculations.

\section{RESULTS AND DISCUSSION}

Figure 5 shows the coefficient of friction curve of the studied sample. The data were obtained performing measurements with the settings presented in Table 4.

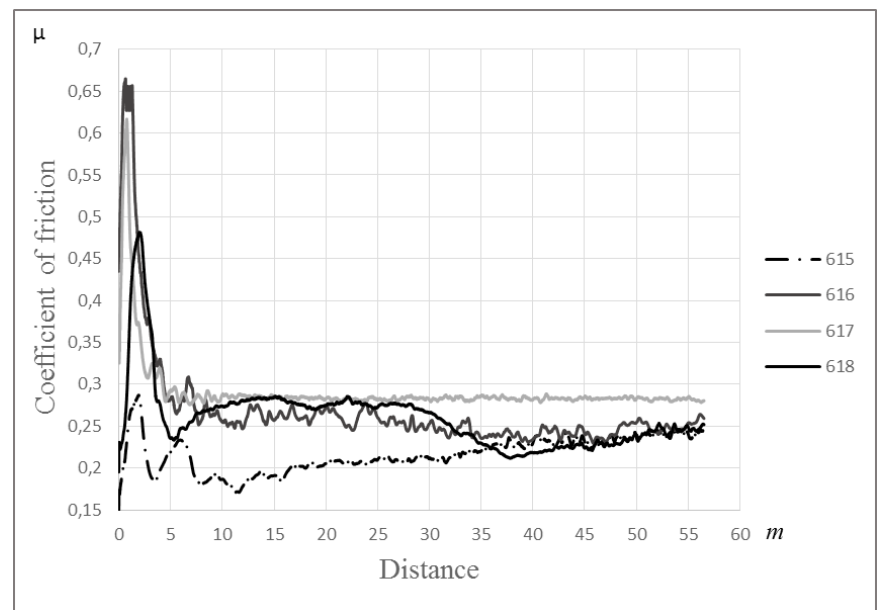

Fig. 5. Summative graph of friction coefficient curves of the studied sample. 
Average Values of Friction Coefficient

\begin{tabular}{|c|c|}
\hline Sample & COF \\
\hline 615 & 0.217 \\
\hline 616 & 0.27 \\
\hline 617 & 0.291 \\
\hline 618 & 0.261 \\
\hline
\end{tabular}

Table 4 shows the average values of friction coefficient of the studied samples. Slight wear of the examined samples was detected, the tribotrack of which could not be accurately measured with Surtronic-25 profilometer. Therefore, the measurements were carried out with profilometer Intra 50. In the measured tribological track area of 615,617 and 618 coatings, a rough surface without the expressed tribological track area was discovered. Figures 6 and 7 serve as an example of it. Out of four examined samples, in case of 616 coatings, tribological track (around $0.4 \mu \mathrm{m}$ depth and $0.2 \mu \mathrm{m}$ width) was identified (see Figure 9), which also indicated unnoticeable wear at the given experimental conditions; the coating thickness of the sample 616 was $4.2 \mu \mathrm{m}$.

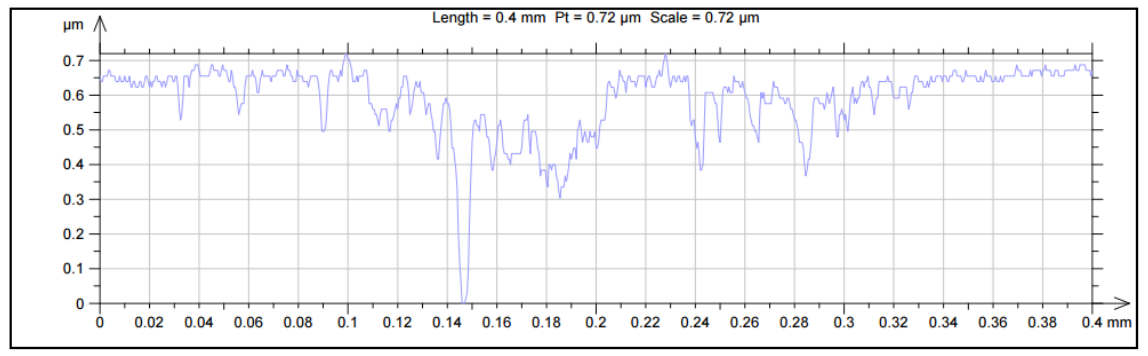

Fig. 6. Tribological track of sample 615.

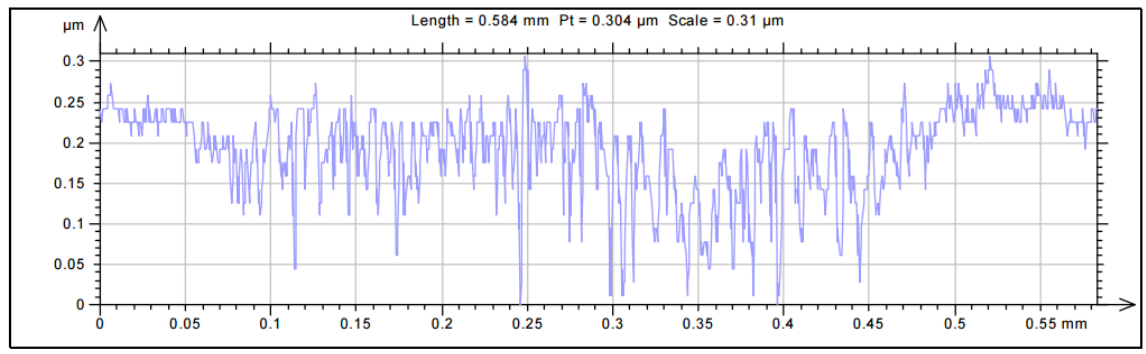

Fig. 7. Tribological track of sample 617.

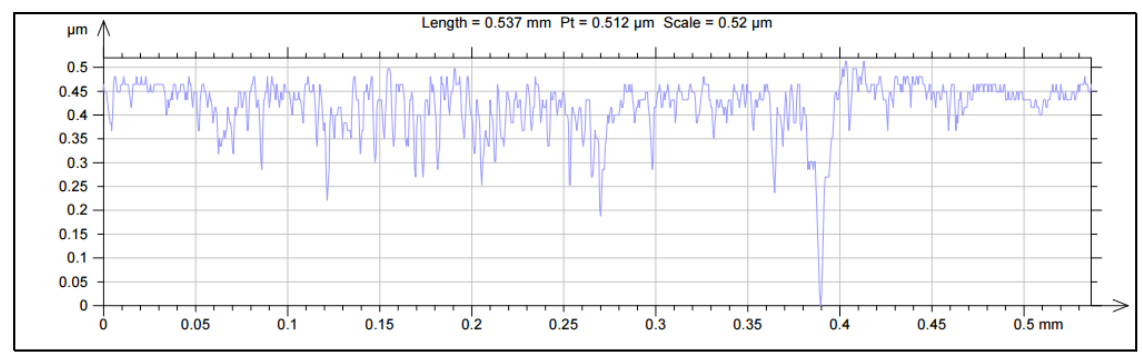

Fig. 8. Tribological track of sample 618. 


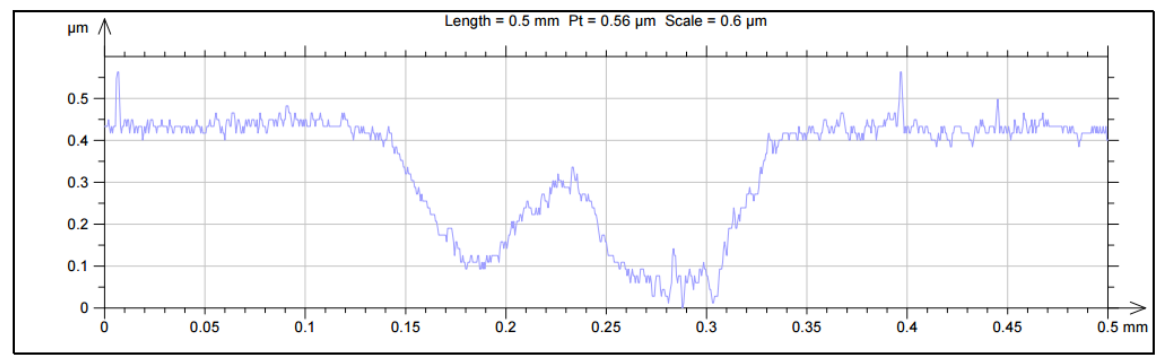

Fig. 9. Tribological track of sample 616.

Due to the absence of expressed tribological tracks, the wear rate values were not calculated for three out of the four investigated coatings.

\section{CONCLUSIONS}

Within the framework of the present research, it has been stated that the Ti/C$\mathrm{N}$ coatings have a lot of pores, so it is the main reason for large values of roughness parameters. In all four samples, slight wear has been detected. Coefficient of friction values range from 0.21 to 0.29 . The sample 615 has the lowest value of friction coefficient obtained under certain conditions, which can be observed in common deposition mode setting table. Wear rate values have not been calculated for the investigated coatings, as no expressed tribotracks have been detected on the coating surface.

\section{ACKNOWLEDGEMENTS}

The present research has been supported by the European Regional Development Fund within the project No.2014/0011/2DP/2.1.1.1.0/13/APIA/VIAA/005.

\section{REFERENCES}

1. Cheng, Y., \& Zheng, Y.F. (2007). Characterization of TiN, TiC and TiCN coatings on Ti-50.6 at.\% Ni alloy deposited by PIII and deposition technique. Surface and Coatings Technology, 201(9-11), 4909-4912.

2. CSM Instruments SA. (2014). Tribometer User Manual R0.1.3a.

3. International Organisation for Standardisation. (2012). LVS EN ISO 25178-2:2012 standard: Geometrical product specifications (GPS) - Surface texture: Areal - Part 2: Terms, definitions and surface texture parameters.

4. Локтев Д., Ямашкин Е. (2007). Основные виды износостойких покрытий. Наноиндустрия, №5, 24-30. 


\title{
PVD Ti/C-N NANOPĀRKLĀJUMU TRIBOLOG̣ISKĀS İPAŠİBAS
}

\author{
A.Leitans, J.Lungevičs, J.Rudzītis, A.Filịpovs
}

\section{Kopsavilkums}

Šajā darbā tika apskatīta un analizēta dažādu pārklājumu, kas palielina virsmu nodilumizturību, triboloǵiskās īpašības. Tika analizēti četri Ti/C-N nanopārklājumi, kuri atšķiras ar pārklājuma uznešanas uzstādījumiem. Pētāmiem paraugiem tika veikti metrologiskie un triboloǵiskie testi: tika nomērīti virsmas raupjuma $2 \mathrm{D}$ un 3D parametri ar moderno profilogrāfu-profilometru un berzes koeficients ar CSM Instruments firmas iekārtu. Pārbaudes eksperimentu laikā tika noteikti raupjuma parametri Ra, Sa, Sz, Str, Sds, Vmp, Vmc un berzes koeficients pie $6 \mathrm{~N}$ slodzes. Pētāmiem paraugiem ir daudz poru, kas ir galvenais iemesls salīdzinoši lielajām raupjuma parametru vērtībām. Kā arī tika konstatēts neliels nodilums visiem četriem paraugiem; To berzes koeficientu vērtības svārstās robežās 0,21-0,29. Pētāmajiem pārklājumiem netika aprēķinātas nodiluma rādītāja vērtības, jo izteikti tribotreki uz pārklājuma virsmas nebija konstatēti.

20.07.2016. 